Гундертайло Юлія Данилівна

молодший науковий співробітник

лабораторії соціальної психології особистості

Інститут соціальної та політичної психології НАПН України,

Київ, Україна

ORCID ID 0000-0001-6959-663X

juligundertaylo@gmail.com

\title{
ОРГАНІЗАЦІЯ СОЦАЛЬНО-ПСИХОЛОГІЧНОГО СУПРОВОДУ ВНУТРІШНЬО ПЕРЕМІЩЕНИХ ОСІБ
}

\begin{abstract}
Проблема соціально-психологічного супроводу ВПО, що набула актуальності в українському суспільстві з початком воєнних дій на сході країни, висвітлюється під кутом зору відновлення психічного здоров'я та психосоціальної підтримки (MHPSS). Соціально-психологічний супровід ВПО розглядається як комплекс специфічних довготривалих і системних заходів щодо психологічної підтримки таких осіб та соціального сприяння їхній інтеграції в місцеві громади в умовах переходу суспільства від війни до миру. Як головну умову результативної психосоціальної підтримки визначено створення сприятливого соціальнопсихологічного середовища на рівні держави та регіональних громад для відновлення життєтворення $\mathrm{i}$ самореалізації ВПО. Розкрито в довгостроковій перспективі потенціал соціально-політичної ситуації для покращення системи охорони психічного здоров'я громадян - системи, яка може стати інституційним підгрунтям продуктивного соціально-психологічного супроводу ВПО. Визначено рівні організації соціально-психологічного супроводу, а саме: макрорівень (стратегії і тактики державної соціальної політики щодо ВПО та інформаційна політика); мезорівень (підтримка громад, що прийняли ВПО, через навчальні та відновлювальні програми для спеціалістів, які взаємодіють з ВПО); мікрорівень (програми соціальнопсихологічного супроводу ВПО на базі організацій місцевого рівня). Розроблено також завдання соціальнопсихологічного супроводу ВПО та відповідні їм критерії оцінювання ефективності програм підтримки. До таких завдань належать: формування навичок соціально-економічної самостійності, реалізація принципів травмочутливості і гендерної чутливості, врахування специфічних потреб цільової групи, сприяння особистісному розвитку, розвінчання стереотипів самосприймання i сприймання. Як перспективу дослідження визначено проведення моніторингу регіональних програм для ВПО за певними критеріями та впровадження їх у практику роботи державних установ та громадських організацій, які надають психосоціальну підтримку ВПО.

Ключові слова: психосоціальна підтримка; соціально-психологічний супровід; психічне здоров'я; ВПО; організація.
\end{abstract}

\section{Yuliia D. Hundertailo}

Junior Researcher,

Laboratory of Social Psychology of Personality,

Institute for Social and Political Psychology, NAES of Ukraine,

Kyiv, Ukraine

ORCID ID 0000-0001-6959-663X

juligundertaylo@gmail.com

\section{ORGANIZATION OF SOCIO-PSYCHOLOGICAL ACCOMPANIMENT OF IDPS}

\begin{abstract}
The problem of socio-psychological accompaniment of IDPs which recently became relevant in Ukrainian society with the beginning of hostilities in the East of Ukraine is highlighted within the framework of mental health psychosocial support (MHPSS). The socio-psychological accompaniment of IDPs is seen as a complex of specific long-term and systematic means of psychological support of such persons, and social assistance to integrate them into local communities under the conditions of transition from war to peace. As the main condition for effective psychosocial support it is defined the creation of a favorable socio-psychological environment at the level of the state and regional communities to restore the IDPs' life-designing and self-realization. It is revealed the long-term potential of the socio-political situation to improve the mental health care system of the citizens, such system may become the institutional basis for the productive socio-psychological accompaniment of IDPs. The levels
\end{abstract}


of organization of socio-psychological accompaniment of IDPs are determined, namely macrolevel (strategies and tactics of the state social policy on IDPs, and the information policy); middle level (support of the IDPs' host communities by means of training and rehabilitation programs for professionals who work with IDPs); microlevel (programs of socio-psychological accompaniment for IDPs based on local organizations). There are also outlined the tasks of socio-psychological accompaniment of IDPs, and the corresponding criteria for support programs evaluation. These tasks are: forming of socio-economic autonomy skills; implementation of trauma and gender sensitivity principles; taking into account the specific needs of the target group; promoting of personal development; debunking of stereotypes on perception and self-perception. As the perspective of research it is defined the monitoring of regional programs for IDPs by certain criteria, and their implementation into the practice of state institutions and public organizations work which deals with psychosocial support for IDPs.

Key words: psychosocial support; socio-psychological accompaniment; mental health; IDPs; organization.

Постановка проблеми. У зв'язку з воєнним конфліктом на сході країни українське суспільство зіткнулося з цілою низкою загроз і зазнало, відповідно, суттєвих змін. Одним із наслідків цих подій стало виникнення цілого прошарку людей, які безпосередньо зазнали впливу травматичної ситуації. Так, Міністерством соціальної політики України станом на березень 2019 р. зареєстровано близько 1,3 млн внутрішньо переміщених осіб (ВПО). Тому сьогодні, у період переходу від війни до миру, особливої гостроти набуло питання соціально-психологічного супроводу ВПО.

В Україні на державному рівні зроблено певні кроки до регуляції цієї сфери, зокрема прийнято Стратегію інтеграції внутрішньо переміщених осіб та впровадження довгострокових рішень щодо внутрішнього переміщення на період до 2020 року (затверджена розпорядженням Кабінету Міністрів України № 909-р. від 15 листопада 2017 р.), розроблено план заходів щодо ії реалізації та впровадження довгострокових рішень щодо внутрішнього переміщення на період до 2020 р. (затверджений розпорядженням Кабінету Міністрів України № 944-р. від 21 листопада 2018 р.). На регіональному рівні, однак, ці розпорядження не завжди знаходять своє втілення. Так, аналіз регіональних програм інтеграції ВПО (Лоюк, 2019) показав, що ціла низка завдань і досі залишається поза увагою місцевої влади. Приміром, у деяких областях не плануються заходи щодо соціально-психологічної підтримки ВПО, а там, де частка таких осіб не перевищує 5\%, ця група здебільшого “розчиняється" в громаді, стає “невидимою”, тобто там неможливо (оскільки немає докладної звітності) оцінити стан реалізації плану заходів щодо ВПО. Попри зміни в соціально-політичній ситуації питання інтеграції ВПО в територіальні громади не втрачає своєї актуальності, оскільки лише $22 \%$ ВПО повідомили про свій намір повернутися після закінчення конфлікту в місця свого проживання до переміщення (Звіт..., 2019, с. 36). На цей час “... ВПО й досі мають більш сильне почуття належності до громади у своєму колишньому місці проживання, ніж до громади в нинішньому місці проживання. Загалом про “дуже сильне” або “сильне” почуття належності до громади в попередньому місці проживання повідомив 41\% ВПО, у порівнянні з 28\% - до громади в нинішньому місці проживання...” (там само, с. 47). Отже, проблематика соціально-психологічного супроводу ВПО на новому місці проживання потребує пильної уваги спільноти психологів.

Аналіз останніх досліджень і публікацій, виокремлення нерозв'язаних частин загальної проблеми. У контексті допомоги ВПО у світі здебільшого використовують поняття "Mental health and psychosocial support” (MHPSS) - психічне здоров'я та психосоціальна підтримка. Під MHPSS треба розуміти будь-яку підтримку, що сприяє психічному здоров'ю та психосоціальному благополуччю людей. Ідеться як про лікування ПТСР, так і про використання ресурсів громади для відновлення відчуття благополуччя.

Якщо раніше основні зусилля гуманітарної допомоги в кризових ситуаціях були зосереджені на задоволенні базових потреб (забезпечення водою, їжею іт. ін.), то останні тенденції полягають у включенні MHPSS у стандартні підходи до розроблення і реалізації гуманітарної допомоги в кризових ситуаціях як на національному рівні, так і в міжнародних організаціях (Weissbecker, Hannd, Shazly, Gao, \& Yentevogel, 2019). Цього року відбулася перша міжнародна конференція з цих питань (The First International Conference on Mental Health and Psychosocial Support in Crisis Situations held in the Netherlands, October 2019), на якій було відзначено, що лише 0,14\% від загальносвітового бюджету на розвиток спрямовується на психосоціальну підтримку, тобто поки що дуже незначна частка осіб, які постраждали, може отримати необхідні послуги щодо підтримання психічного здоров’я.

В Україні перше національне репрезентативне дослідження психічного здоров'я дорослих ВПО було проведено у 2016 р. Виявлено, що поширеність ПТСР у цьому середовищі - 32\% (22\% серед 
чоловіків і 36\% - серед жінок), депресії - 22\% (відповідно 16 і 25\%), тривоги - 17\% (13 і 20\%); також було зафіксовано високий рівень супутніх захворювань (Байярд, Махашвілі, \& Джавахішвілі, 2017, с. 6). Загалом можливості ВПО отримати психосоціальну підтримку поки що не особливо великі у зв'язку 3 браком як відповідних інституцій, так і інших ресурсів.

Сучасні підходи щодо психосоціальної підтримки грунтуються на розвитку резильєнтності громади й особистості (А community-based..., 2008). Експерти зазначають, що ВПО потребують розширеного, комплексного, травма- і гендерно чутливого реагування суспільства на їхні потреби (Гундертайло, 2017). Важливо, щоб система підтримки була клієнтоорієнтованою, міждисциплінарною та координованою, тобто спиралася на контексти часу і місця, країни, конкретної громади та організації й враховувала міжособові стосунки та особливості особи, що потребує соціально-психологічної підтримки.

Соціально-психологічний супровід як різновид психосоціальної підтримки $\epsilon$ спеціально організованою й змодельованою діяльністю, що характеризується тривалістю та систематичністю (Титаренко, 2019). Супровід найчастіше розглядають у контексті медичної або педагогічної підтримки (Мушкевич, 2011; Бовгиря, 2009), однак у випадку затяжного воєнного конфлікту, як це відбувається в Україні, соціально-психологічний супровід може бути одним із варіантів довготривалих рішень для ВПО. На часі формування комплексного підходу до соціально-психологічного супроводу ВПО.

Мета статті - означити основні рівні організації соціально-психологічного супроводу ВПО.

Виклад основного матеріалу дослідження. Проблематика організації соціально-психологічного супроводу ВПО з огляду на соціально-культурну специфіку нашої країни та ії регіональні відмінності лежить у площині використання напрацювань щодо психічного здоров'я та психосоціальної підтримки (MHPSS). Уже зрозуміло, що рішення повинні ухвалюватися на довгострокову перспективу, тому планування організації соціально-психологічного супроводу ВПО є виправданим кроком як із соціальноекономічної, так і соціально-психологічної точки зору. Отож ми розглядаємо соціально-психологічний супровід ВПО як комплекс специфічних довготривалих і системних заходів щодо психологічної підтримки та соціального сприяння інтеграції таких осіб у місцеві громади в умовах переходу від війни до миру.

Належить розуміти, що психосоціальна підтримка ВПО є завданням загальнодержавного рівня і в цій сфері, безперечно, потрібне співробітництво з відповідними органами і міністерствами, оскільки саме від заданих соціально-політичних векторів будуть залежати конкретні практичні заходи в місцевих громадах, ініційовані як виконавчою владою, так і громадянським суспільством.

Попри те, що гуманітарні кризи в цілому негативно впливають на психічне здоров'я населення, дослідження переконливо доводять, що в довготривалій перспективі країни отримують шанс на суттєве покращення системи охорони психічного здоров'я (Epping-Jordan et al., 2015), оскільки країни з низьким і середнім рівнем доходу (до яких належить і Україна) здебільшого не мають розгорнутої і сталої системи охорони психічного здоров'я на рівні громад. У разі надзвичайних ситуацій чи воєнних конфліктів психічне здоров'я населення привертає увагу, у тому числі 3МI, і спонукає міжнародні й благодійні організації вкладати ресурси в ці сфери. Це відкриває можливості для розвитку служби охорони психічного здоров'я держави, що може бути використано в Україні для просування змін у цій галузі. Хоча гуманітарна допомога передбачає короткострокові проєкти, однак потенціал цих процесів стає детонатором значного поштовху до суттєвого реформування системи охорони психічного здоров'я, оскільки підвищується обізнаність населення в цій царині й суттєво збільшується кількість спеціалістів у відповідній сфері, зростає їхній кваліфікаційний рівень. Було названо основні умови, які забезпечують довготривалу реформу служби охорони психічного здоров'я громадян, а саме: довгострокове планування реформи системи охорони психічного здоров'я в державі, охоплення широкого кола проблем психічного здоров'я, активна участь уряду, координація роботи різних агентств. Водночас ці процеси потребують енергійної підтримки місцевих спеціалістів, що вже підвищили свою кваліфікацію та підтримали реформу. Важливі також демонстраційні проєкти й широке коло громадської дієвої підтримки. Саме розвинуті служби охорони психічного здоров'я можуть стати базою для реалізації соціальнопсихологічного супроводу ВПО.

Головною умовою досягнення поставлених цілей ми вважаємо створення сприятливого середовища, яке має сформувати “friendly" простір для ефективного життєконструювання та 
самореалізації ВПО, адже наразі ця група стикається (коли йдеться про сприйняття місцевими громадами) з певними соціальними стереотипами; також має місце стигматизація і самостигматизація.

На нашу думку, соціально-психологічний супровід ВПО слід організовувати на трьох рівнях, які послідовно і комплексно могли б забезпечити ефективний процес інтеграції ВПО в місцеві громади, створити доброзичливий простір для місцевих ініціатив, підвищити резильєнтність на рівні держави.

Макрорівень. Пов'язаний з виробленням стратегії і тактики державної соціальної політики щодо внутрішньо переміщених осіб, що грунтується на принципі розширеного, комплексного, травма- i гендерно чутливого реагування на потреби ВПО. Якщо моніторинг соціально-економічного стану ВПО уже налагоджено, то відповідне коригування роботи Міністерства 3 питань тимчасово окупованих територій і внутрішньо переміщених осіб (МТОТ) потребує покращення. Зрозуміло, на узагальнення численних наукових досліджень з проблематики ВПО в Україні, осмислення та впровадження результатів цих напрацювань ще потрібен певний час. Варто зазначити, що цього року для розв'язання нагальних проблем ВПО створено експертну раду при МТОТ.

Інформаційна політика щодо внутрішньо переміщених осіб має показувати позитивні аспекти присутності ВПО в нових громадах; соціальні, культурні та фінансові преференції, які отримали в результаті цього місцеві жителі. Потрібна тісна співпраця із журналістами та місцевими органами влади, мають діяти спеціалізовані програми підтримки публікацій про ВПО (можливо, гранти чи квоти в державних медіа). Зокрема, використовуючи інформаційні кампанії, потрібно вивчати та розвінчувати соціальні стереотипи щодо ВПО.

Мезорівень. Соціально-психологічна підтримка внутрішньо переміщених осіб полягає також у підтримці громад, які прийняли ВПО, і спеціалістів, що працюють з ними. Зокрема, потрібні комплексні державні програми психологічної підтримки вчителів, соціальних працівників, державних службовців, у тому числі в онлайнових форматах. Для збереження психологічного і соматичного здоров'я кадрів варто створити спеціальні навчальні короткострокові програми, які б забезпечували необхідні знання та сприяли формуванню потрібних навичок, підтриманню щоденних практик й організації системи підтримки на робочому місті, а також надавали працівникам можливість здорової рекреації. Така робота сприяла б запобіганню вітальної травми у спеціалістів та вторинній травматизації ВПО.

Мікрорівень. Створення програм соціально-психологічного супроводу ВПО на базі організацій місцевого значення, що враховують як особливості групи ВПО, так і регіональну специфіку. Програми мають базуватися на використанні ресурсів місцевих громад, а саме потенціалу громадських, культурних та освітніх центрів.

Отже, створення сприятливого середовища дасть змогу забезпечити більш ефективне відновлення життєвого світу ВПО за рахунок зниження рівня фонового стресу від взаємодії з державними органами, місцевими жителями та інформаційним простором.

Соціально-психологічний супровід ВПО, на нашу думку, має вирішувати такі завдання:

1. Формувати активну життєву позицію ВПО та запобігати соціальній інвалідизації таких осіб за рахунок підвищення їхньої фінансової компетентності чи/та розширення діапазону їхніх умінь та навичок. Тобто, складачи програми підтримки, слід заохочувати людей до самостійності i відповідальності, спиратися на їхній досвід і можливості, уникати патерналізму.

2. Відповідати на актуальні потреби цільової групи та враховувати соціально-культурні контексти. У процесі створення місцевих програм активно співпрацювати 3 ключовими інформаторами ВПО та іншими представниками, планувати певну варіативну складову програми, яка даватиме змогу реагувати на зміни, оскільки супровід зазвичай розтягнутий у часовій перспективі.

3. Реалізовувати принципи травмочутливості та гендерної чутливості, тобто враховувати як гендерні відмінності, так і особливості людей, що пережили травматичні події (постійні стреси, підвищена тривожність і т. ін.).

4. Активізувати власні ресурси ВПО, розвивати у них суб'єктність. Упровадження програм має підкріплюватись елементами, спрямованими на розвиток емоційної сфери, навичок саморегуляції, комунікативних умінь тощо.

5. Запобігати явищу стигматизації і самостигматизації ВПО. Під час розроблення і реалізації програм соціально-психологічного супроводу ВПО слід також оцінювати їх щодо ймовірності стигматизації і самостигматизації, а саме усталювання в суспільстві соціальних стереотипів щодо ВПО. 
3 огляду на окреслені завдання пропонуємо такі критерії оцінювання програм соціальнопсихологічного супроводу ВПО:

1) формування навичок соціально-економічної самостійності;

2) реалізація принципів травмочутливості та гендерної чутливості;

3) врахування специфічних потреб цільової групи;

4) сприяння особистісному розвитку;

5) розвінчання стереотипів самосприймання та сприймання.

Перелічені критерії можуть бути використані як місцевою владою, так і громадськими організаціями для більш ефективної психосоціальної підтримки ВПО. Вони можуть також слугувати теоретичною базою під час розроблення і в процесі рецензування програм соціально-психологічного супроводу. Завдяки врахуванню цих критеріїв психосоціальна підтримка ВПО буде більш комплексною, а проведена робота дасть змогу запобігти виникненню як психологічних, так і соціально-психологічних проблем у населення в цілому.

Практична/соціальна значущість дослідження. Виокремлені критерії можуть бути використані під час створення та затвердження місцевих програм соціально-психологічного супроводу ВПО як на рівні обласних і районних адміністрацій, так і на рівні місцевих ініціатив.

Висновки. Соціально-психологічний супровід ВПО - це комплекс специфічних довготривалих і системних заходів щодо психологічної підтримки та соціального сприяння їх інтеграції у місцеві громади внутрішньо переміщених осіб в умовах переходу суспільства від війни до миру. Головною умовою ефективної підтримки таких осіб $є$ створення сприятливого для них соціально-психологічного середовища на рівні держави, яке має сформувати “friendly" простір для ефективного життєконструювання та самореалізації ВПО. У довгостроковій перспективі можна сподіватися на суттєве покращення системи охорони психічного здоров'я, яка має стати інституційним підгрунтям для продуктивного соціально-психологічного супроводу ВПО.

Соціально-психологічний супровід внутрішньо переміщених осіб слід організовувати на трьох рівнях, які послідовно і комплексно могли б забезпечити ефективний процес інтеграції ВПО в місцеві громади, створити доброзичливий простір для місцевих ініціатив, підвищити резильєнтність на рівні держави. Макрорівень пов'язаний з виробленням стратегії і тактики державної соціальної політики щодо ВПО та формуванням інформаційної політики. Мезорівень передбачає підтримку громад, що прийняли ВПО, зокрема реалізацію навчальних та відновлювальних програм для спеціалістів, які взаємодіють 3 ВПО. Мікрорівень стосується створення програм соціально-психологічного супроводу ВПО на базі організацій місцевого рівня, що враховують як особливості спільноти ВПО, так і регіональну специфіку.

3 огляду на завдання соціально-психологічного супроводу внутрішньо переміщених осіб визначено критерії оцінювання програм для ВПО: формування навичок соціально-економічної самостійності, реалізація принципів травмочутливості і гендерної чутливості, врахування специфічних потреб цільової групи, сприяння особистісному розвитку, розвінчування стереотипів самосприйняття та сприйняття.

Перспективи подальших досліджень. Проведення моніторингу регіональних програм для ВПО за нашими критеріями, упровадження їх у практику роботи державних установ та громадських організацій є перспективним напрямом досліджень. Також (зокрема) планується розроблення та апробація місцевих програм соціально-психологічного супроводу ВПО спільно з партнерами.

\section{Список використаних джерел}

Байярд, Р., Махашвілі, Н., \& Джавахішвілі, Дж. (2017). Приховані наслідки конфлікту. Проблеми психічного здоров'я та доступ до послуг серед внутрішньо переміщених осіб в Україні. International Alert, Глобальна ініціатива у психіатрії, Тбілісі, Лондонська школа гігієни і тропічної медицини, за фін. підтримки Європейського Союзу. Київ: $\begin{array}{lllll}\text { Nick Wilmot } & \text { Creative. } & \text { Взято } & 3 & \text { https://www.international- }\end{array}$ alert.org/sites/default/files/Ukraine_HiddenBurdensConflictIDPs_UK_2017.pdf

Бовгиря, Н. В. (2009). Психолого-педагогічний супровід дітей в умовах модернізачї̈ навчально-виховного проиесу. Дубровиця. Взято з http://navigator.rv.ua/index.php

Гундертайло, Ю. Д. (2017). Арт-терапевтичні технології надання психологічної допомоги внутрішньо переміщеним особам. В Т. М. Титаренко (Ред.), Способи підвищення соціально-адаптивних можливостей людини 
в умовах переживання наслідків травматичних подій: методичні рекомендації. Кропивницький: Імекс-ЛТД, с. 6169.

Звіт національної системи моніторингу ситуації з внутрішньо переміщеними особами. Червень 2019 року (2019). Міністерство соціальної політики України та ін.; підготовлено за фінансування Свропейського Союзу. Київ:

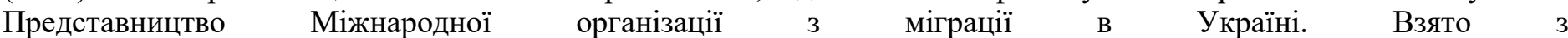
http://iom.org.ua/sites/default/files/nms_round_14_ukr_web.pdf

Лоюк, І. (2019). Регіональні програми інтеграчії внутрішньо переміщених осіб в Украӥні у 2018-2019 роках. звіт за результатами моніторингу. Київ: Stabilization Support Services. Взято 3 https://radnyk.org/reports/monitoring_2018-2019.pdf

Мушкевич, М. I. (2011). Поняття супроводу у сучасній психологічній науці. Проблеми загальної та педагогічної психологї, т. ХІІІ, ч. 1, с. 287-294.

Титаренко, Т. М. (2019). Травмочутливий психологічний супровід як медіатор конструктивних особистісних трансформацій. В Філософсько-соиіологічні та психолого-педагогічні проблеми підготовки особистості до виконання завдань в особливих умовах, Матеріали науково-практичної конференції (c. 274-278). Київ: Національний університет оборони України імені Івана Черняховського.

A Community-based Approach in UNHCR Operations (2008). Office of the United Nations High Commissioner for Refugees. Geneva. Retrieved from https://www.unhcr.org/47f0a0232.pdf

Epping-Jordan, J. E., van Ommeren, M., Ashour, H. N. et al. (2015). Beyond the Crisis: Building Back Better Mental Health Care in 10 Emergency-Affected Areas Using a Longer-Term Perspective. International Journal of Mental Health Systems, 9: 15. doi: 10.1186/s13033-015-0007-9

Mind the Mind Now: International Conference on Mental Health and Psychosocial Support in Crisis Proceedings (7-8 October 2019). Government of the Netherlands, the Ministry for Foreign Trade and Development Cooperation. Amsterdam. Retrieved from

https://www.government.nl/documents/

publications/2019/10/18/mind the mind now conferce special

Weissbecker, I., Hanna, F., El Shazly, M., Gao, J., \& Ventevogel, P. (2019). Integrative Mental Health and Psychosocial Support Interventions for Refugees in Humanitarian Crisis Settings. In Wenzel, T., \& Drohpek, B. (Eds). An Uncertain Safety Integrative Health Care for the 21st Century Refugees. Springer, Cham. doi: 10.1007/978-3-319-72914$5 \_6$

\section{References}

A Community-based Approach in UNHCR Operations (2008). Office of the United Nations High Commissioner for Refugees. Geneva. Retrieved from https://www.unhcr.org/47f0a0232.pdf (in English)

Bayyard, R., Makhashvili, N., \& Dzhavakhishvili, Dz. (2017). Prykhovani naslidky konfliktu. Problemy psykhichnoho zdorovia ta dostup do posluh sered vnutrishno peremishchenykh osib v Ukraini [Concealed Consequences of the Conflict. Mental Health Problems and Access to Services for Internally Displaced Persons in Ukraine]. International Alert, Global Initiative in Psychiatry - Tbilisi, London School of Hygiene and Tropical Medicine; for the fin. support of the European Union. Kyiv: Nick Wilmot Creative. from https://www.international alert.org/sites/default/files/Ukraine_HiddenBurdensConflictIDPs_～UK_2017.pdf (in Ukrainian)

Bovhyrya, N. V. (2009). Psykholoho-pedahohichnyi suprovid ditey v umovakh modernizatsii navchalnovykhovnoho protsesu [Psychological and pedagogical support of children in the conditions of modernization of educational process]. Dubrovytsia. Retrieved from http://navigator.rv.ua/index.php (in Ukrainian)

Epping-Jordan, J. E., van Ommeren, M., Ashour, H. N. et al. (2015). Beyond the Crisis: Building Back Better Mental Health Care in 10 Emergency-Affected Areas Using a Longer-Term Perspective. International Journal of Mental Health Systems, 9: 15. doi: 10.1186/s13033-015-0007-9 (in English)

Hundertaylo, Yu. D. (2017). Art-terapevtychni tekhnolohii nadannia psykholohichnoi dopomohy vnutrishno peremishchenym osobam [Art-Therapeutic Technologies Providing Psychological Assistance to Internally Displaced Persons]. In T. M. Tytarenko (Ed.), The ways of human social-adaptive possibilities increasing in the conditions of the consequences of traumatic events experience: methodical recommendations (pp. 61-69). Kropyvnytskyi: Imex-LTD. (in Ukrainian)

Loyuk, I. (2019). Rehionalni prohramy intehratsii vnutrishno peremishchenykh osib v Ukraini u 2018-2019 rokakh. Zvit za rezultatamy monitorynhu [Regional Integration Programs for Internally Displaced Persons in Ukraine in 2018-2019. Report on the Results of Monitoring]. Kyiv: Stabilization Support Services. Retrieved from https://radnyk.org/reports/monitoring_2018-2019.pdf (in Ukrainian) 
Mind the Mind Now: International Conference on Mental Health and Psychosocial Support in Crisis Proceedings (7-8 October 2019). Government of the Netherlands, the Ministry for Foreign Trade and Development Cooperation. Amsterdam. Retrieved from https://www.government.nl/documents/publications/ 2019/10/18/mind-the-mind-nowconference-special (in English)

Mushkevych, M. I. (2011). Poniattia suprovodu u suchasnii psykholohichnii nautsi [The concept of support in modern psychological science]. Problemy zahalnoi ta pedahohichnoi psykholohii [Problems of General and Educational Psychology], vol. XIII, part 1, pp. 287-294. (in Ukrainian)

Tytarenko, T. M. (2019). Travmochutlyvyi psykholohichnyi suprovid yak mediator konstruktyvnykh osobystisnykh transformatsii [Trauma-Sensitive Psychological Support as a Mediator of Constructive Personal Transformations]. In Filosofsko-sotsiolohichni ta psykholoho-pedahohichni problemy pidhotovky osobystosti do vykonannia zavdan v osoblyvykh umovakh [Philosophical, Sociological and Psychological-Pedagogical Problems of Preparing a Person to Perform Tasks in Special Conditions: Proceedings of the scient.-pract. conference] (pp. 274-278). Kyiv: The National Defense University of Ukraine named after Ivan Cherniakhovskyi. (in Ukrainian)

Weissbecker, I., Hanna, F., El Shazly, M., Gao, J., \& Ventevogel, P. (2019). Integrative Mental Health and Psychosocial Support Interventions for Refugees in Humanitarian Crisis Settings. In Wenzel, T., \& Drohpek, B. (Eds.), An Uncertain Safety Integrative Health Care for the 21st Century Refugees. Springer, Cham. doi: 10.1007/978-3-319-729145_6 (in English)

Zvit natsionalnoi systemy monitorynhu sytuatsii z vnutrishno peremishchenymy osobamy. Cherven 2019 roku [Report of the National System for Monitoring the Situation with Internally Displaced Persons. June 2019]. (2019). Ministry of Social Policy of Ukraine, etc.; prepared for financing by the European Union. Kyiv: The International Organization for Migration Mission in Ukraine. Retrieved from http://iom.org.ua/sites/default/files/nms_round_14_ukr_web.pdf (in Ukrainian) 